ZatącZnil

\title{
WOKÓŁ ZARZĄDZANIA KULTURA. REZULTATY BADANIA ANKIETOWEGO
}

OPRACOWANIE:

PATRYK DZIURSKI

Kolegium Zarządzania i Finansów, Szkoła Główna Handlowa w Warszawie Collegium of Management and Finance, SGH Warsaw School of Economics pd54550@sgh.waw.pl

KAMA PAWLICKA

ANNA WRÓBLEWSKA
Wydział Nauk Humanistycznych UKSW

Faculty of Humanities, Cardinal Stefan Wyszyński University in Warsaw kamapawlicka@hotmail.com

Wydział Nauk Humanistycznych UKSW

Faculty of Humanities, Cardinal Stefan Wyszyński University in Warsaw annadorotawroblewska@gmail.com

\section{WPROWADZENIE}

Kultura fascynowała wielu badawczy od stuleci, ale dopiero w drugiej połowie XX wieku zainteresowali się nią ekonomiści ${ }^{1}$. Obecnie obszar badawczy, jakim jest ekonomia kultury, stanowi część ekonomii, a na całym świecie powstają publikacje dotyczące ekonomicznych aspektów kultury². Współcześnie wydaje się, że obok ekonomii kultury wykształca się nowy obszar - zarządzanie kulturą, cieszące się zainteresowaniem wielu badaczy oraz wymagające zdefiniowania i opisania zarówno pod względem zakresu znaczeniowego, jak i odpowiednich metodologii badawczych.

Wiosną 2017 roku przeprowadziliśmy ankietę wśród badaczy zajmujących się szeroko rozumianymi sektorami kreatywnymi, a także wśród

1 R. Kasprzak, Przemysty kreatywne w Polsce: uwarunkowania i perspektywy, Warszawa 2013, s. 29; K. Stachowiak, Problemy metodologiczne badania sektora kreatywnego, „Rozwój Regionalny i Polityka Regionalna” 2015, nr 30, s. 14-16.

2 Zob. np. U. Grzelońska, Ekonomiczna strona kultury, Warszawa 2016; D. Ilczuk, Ekonomika kultury, Warszawa 2012; D. Throsby, Ekonomia i kultura, tłum. O. Siara, Warszawa 2010; R. Towse, Ekonomia kultury. Kompendium, tłum. Ł. Skrok, H. Dębowski, K.L. Pogorzelski, Warszawa 2011. 
menedżerów, często łączących doświadczenie w tej materii z praktyką akademicką. Na naszą prośbę odpowiedziało dwadzieścia osób. Wyniki tego - w gruncie rzeczy autorefleksyjnego - badania prezentujemy poniżej. Subiektywne podejście respondentów do problemów, różnorodność stanowisk, a w wielu punktach także ich zbieżność, tworzą fundament, na którym można budować poszukiwania badawcze w tym obszarze i odnaleźć, wciąż liczne, biały plamy.

Zdecydowaliśmy się zadać naszym respondentom następujące pytania: Czy Pana/i zdaniem zarządzanie kulturą należy do nauk ekonomicznych, czy też jest subdyscypliną kulturoznawstwa? Co wyróżnia zarządzanie kulturą na tle innych nauk? Który obszar zarządzania kulturą i jakie zagadnienia należy rozwinąć: obszar przedmiotowy (np. teoria zarządzania, zarządzanie strategiczne, zarządzanie kapitałem ludzkim, przywództwo, marketing i inne) czy obszar podmiotowy (np. sektory kreatywne, sektory kultury, rynek audiowizualny, teatry i inne)? Czy modele i metody zarządzania mogą zostać zastosowane w zarządzaniu kulturą? Jeśli tak, to jakie? Czy może Pan/i wskazać metody i modele z zakresu kulturoznawstwa, które można zastosować w zarządzaniu kulturą? Czy Pana/i zdaniem można mówić w Polsce o istnieniu środowiska badaczy zarządzania kulturą? Proszę wskazać liczące się ośrodki. Czy istnieje współpraca między ośrodkami naukowymi oraz między ośrodkami naukowymi a instytucjami kultury? Czy wytwarzają się kanały komunikacji (publikacje, konferencje, nieformalne grupy)? ${ }^{3}$

W odpowiedzi na temat aplikacji teorii zarządzania do domeny kultury dr Agata Siwiak (UAM), która jest akademiczką oraz aktywną kuratorką i producentką, stwierdziła:

Bardzo cenię tę bizawodowość. Kiedy czytam artykuły dotyczące zarządzania w kulturze, to miewam często wrażenie, że brakuje w nich podstaw praktycznych. Wierzę, że badaczom zarządzania pomogłaby możliwość wglądu w procesy produkcji sztuki. Mam poczucie, że zarządzanie kulturą wciąż traktuje się jako wyizolowaną naukę - brakuje interdyscyplinarności, poszukiwań wędrujących wzdłuż i wszerz zarządzania, estetyki, teorii sztuki,

3 W artykule tym nie zostały ujęte odpowiedzi na jedno pytanie (na temat szans i barier w zarządzaniu kulturą), które odnosi się do innego obszaru badań. 
socjologii, antropologii, co przekłada się na lukę w badaniach jakościowych. Brakuje języka, który łączyłby wszystkie te przestrzenie.

Natomiast prof. Mieczysław Morawski (UE we Wrocławiu) stwierdził, że:

Mamy tu do czynienia z próbą połączenia dwóch żywiołów. Z jednej strony kultura, splatająca zdarzenia, procesy i przedsięwzięcia oparte na oryginalności, wyjątkowości i niepowtarzalności, twórczej odwadze i przełamywaniu różnych tabu, generująca wartości filozoficzne, ekspresywne, estetyczne, edukacyjne i inne, których percepcja uzależniona jest od indywidualnych preferencji i wrażliwości. Zarządzanie to drugi żywioł, oferujący zbiór sprawdzonych, wielokrotnie wykorzystywanych narzędzi działania, których stosowanie sprzyja osiąganiu sukcesów w realizacji celów. Dzięki zarządzaniu - w rozumieniu naukowych koncepcji i metod menedżerskich oraz praktycznych, sprawdzonych dyrektyw postępowania - przedsięwzięcia kreowane, wzbogacane i realizowane w domenie kultury mają większą szansę na wielowymiarowy sukces, $w$ tym komercyjny, ekonomiczno-finansowy, organizacyjny, marketingowy. Specyfiki połączenia obu tak różnych żywiołów można upatrywać właśnie w kategoriach paradoksów i sprzeczności, we współistnieniu różnych dopuszczalnych alternatyw działania na styku oryginalnej sztuki i racjonalnego zarządzania. To z kolei powinno się przekładać na niezwykłą kreatywność zarządzania kulturą, w której każdy projekt oferujący widzom/słuchaczom/czytelnikom wartości oparte na przeżyciach i odpowiadające przedsięwzięciu narzędzia finansowe, organizacyjne czy marketingowe tworzyć będzie innowacyjne rozwiązania. Daje to wyobrażenie o wielu potencjalnych problemach i procesach badawczych, które mogą być realizowane przez heterogeniczne zespoły badawcze, składające się z przedstawicieli różnych nauk. Generalizując, paradoksy i sprzeczności wnoszone przez odmiennie konstytuowane: kulturę i zarządzanie, kreatywność i innowacyjność wynikającą z planowania i realizacji projektów, różne tradycje i paradygmaty naukowe osób angażujących się w zarządzanie kulturą - wszystko to może decydować o jego odmienności i specyfice.

\section{ZARZĄDZANIE KULTURĄ WOBEC PODZIAŁU NAUK I DYSCYPLIN}

Czy zarządzanie kulturą przynależy do nauk ekonomicznych, czy do kulturoznawstwa? Nawet pobieżna analiza odpowiedzi na tak sformułowane pytanie nie daje jednoznacznej odpowiedzi. Część z ankietowanych uważa, że 
zarządzanie kulturą należy do nauk ekonomicznych, w szczególności nauk o zarządzaniu, część natomiast, że jest częścią kulturoznawstwa, a pozostali wskazują na jego interdyscyplinarny czy multidyscyplinarny charakter. Powyższy problem następująco opisuje prof. Urszula Grzelońska (PAN):

Jeśli godzimy się ze stanowiskiem, że zarządzanie należy do dziedziny nauk ekonomicznych, to musimy konsekwentnie zgodzić się, że zarządzanie kulturą również należy do tej dziedziny, i to bez względu na to, czy mówimy o zarządzaniu kulturą, czy w kulturze, czy o zarządzaniu instytucjami kultury. [...] O ile kulturoznawstwo jako przedmiot edukacji jest stosunkowo dobrze zakorzenione w Polsce, to jako przedmiot badań charakteryzuje się ciągle różnymi niekonsekwencjami, będącymi skutkiem tworzenia go na zasadzie „zszywania” wielu problemów rozpatrywanych do niedawna oddzielnie, w ramach różnych dyscyplin naukowych, i stąd nie mam wątpliwości, że w jego ramach może pomieścić się także zarządzanie kulturą.

Pokrywa się to z opinią dra hab. Konrada Klejsy (UŁ), który wskazuje, że: Polskie kulturoznawstwa to z jednej strony filozofia kultury, z drugiej zaś określenie „ramowe”, pod którym kryją się bądź studia nad kulturami świata („kulturoznawstwo bliskowschodnie” itp.), bądź subdyscypliny dotyczące poszczególnych rodzajów twórczości artystycznej, takie jak filmoznawstwo czy teatrologia.

Dr Łukasz Wróblewski (WSB Dąbrowa Górnicza) stwierdza natomiast, że:

Sektor kultury jest wewnętrznie bardzo zróżnicowany. W jego ramach działają zarówno publiczne, jak i prywatne instytucje, instytucje niedochodowe oraz instytucje zorientowane na zysk, instytucje o orientacji produktowej oraz rynkowej, instytucje kreacji i upowszechniania dzieł sztuki. Wszystko to sprawia, że trudno znaleźć tu wspólny mianownik - uniwersalne narzędzia, metody czy strategie, które mogą mieć zastosowanie we wszystkich podmiotach sektora kultury. Ponadto ciągle panuje sytuacja braku porozumienia w podstawowych kwestiach teoretycznych i metodologicznych, dająca o sobie znać choćby w zróżnicowanym sposobie rozumienia głównych pojęć służących do opisu rzeczywistości społeczno-kulturowej, występujących w niej zjawisk i procesów. 


\section{PROBLEMY DEFINICYJNE}

Kwestią problematyczną w dyskusji nad zarządzaniem kulturą jest to, co prof. Tadeusz Stryjakiewicz (UAM) trafnie określił jako „brak precyzji pojęciowej”, a co może odnosić się także do zadanych przez nas pytań:

Czy mówimy o zarządzaniu kulturą, czy o zarządzaniu w kulturze; lub: czy zarządzanie kulturą traktujemy jako naukę, czy jako wiedzę praktyczną? Jeśli chodzi o zarządzanie instytucjami i organizacjami kultury, wówczas to, co w ankiecie nazwane jest „zarządzaniem kulturą”, bardziej związane jest $\mathrm{z}$ naukami ekonomicznymi (a nawet ekonomiczno-prawnymi), jeśli zaś chodzi o kulturę jako sferę życia i aktywności człowieka, wówczas zwiększa się rola kulturoznawstwa.

W podobnym tonie wypowiedział się dr Krzysztof Stachowiak (UAM), który wskazał, że: „przede wszystkim należy odróżnić zarządzanie kulturą od nauki o zarządzaniu kulturą. W pierwszym przypadku mamy do czynienia z działaniami związanymi z kierowaniem organizacjami kultury (teatry, muzea, galerie sztuki itp.), a w drugim - z dziedziną wiedzy, której przedmiotem zainteresowania są te działania”. Dr Katarzyna Plebańczyk (UJ) zwróciła natomiast uwagę, że:

Odpowiedź na pytanie o definicję zarządzania w kulturze wymaga sprecyzowanego podejścia do pojęcia „kultura”. Od lat 90. w Polsce, a trochę wcześniej i poza Polską, świat nauki, ale i polityki oraz praktyków zarządzania dyskutuje o tym, co jest kulturą. Prowadzi nas to do ustalenia, że konieczne jest stosowanie definicji indywidualnych, przyjmowanych na potrzeby konkretnych działań (Raport KEA z 2004 r. o znaczeniu gospodarczym sektora kultury jest tego najlepszym dowodem, gdyż na jego potrzeby została przyjęta definicja, która wzbudziła spore kontrowersje wśród m.in. ekonomistów kultury). Kiedy mówimy o kulturze, a w konsekwencji o zarządzaniu kulturą, zawsze musimy doprecyzować, co właściwie mamy na myśli, inaczej bowiem pojęcie to odniesiemy do sfery publicznego, instytucjonalnego funkcjonowania kultury, inaczej do sektora pozarządowego, a jeszcze inaczej do biznesu. Kulturą zarządza się z poziomu polityki, ale także $\mathrm{z}$ poziomu organizacji (instytucji, firmy), i stosowane tu narzędzia różnią się między sobą, a czasami są podobne tylko z pozoru (np. różne rozumienie zarządzania strategicznego).

Brak precyzji pojęciowej powoduje chaos definicyjny. Wydaje się jednak, że nie jest to niepokojący fakt, gdyż, jakkolwiek nazywane, zarządzanie 
kulturą jest młodą subdyscypliną naukową. Korzystając z propozycji P. Hirscha oraz D. Levina ${ }^{4}$, można stwierdzić, że obszar zarządzania kulturą znajduje się obecnie w fazie wschodzącego zainteresowania (emerging excitement), a w przyszłości wejdzie w fazę weryfikowania wyzwań (validity challenge), następnie zaś w fazę porządkowania typologii (tidying up with typologies). W początkowych fazach rozwoju obszaru badawczego nieprecyzyjność oraz nadmiar stosowanych pojęć jest stanem naturalnym, wraz $z$ rozwojem natomiast zmniejsza się chaos definicyjny oraz wykształcają się paradygmaty, a badacze tworzą nowe teorie.

\section{PRZYNALEŻNOŚĆ DYSCYPLINARNA ZARZĄDZANIA KULTURA}

Cześć ekspertów jednoznacznie wskazała, że zarządzanie kulturą przynależy do nauk ekonomicznych, w szczególności do nauk o zarządzaniu. Mieczysław Morawski stwierdził, iż:

Wszędzie tam, gdzie podejmuje się próby zarządzania, również zarządzania kulturą, mamy do czynienia z pierwiastkiem racjonalności. Oznacza to przede wszystkim działanie przemyślane, zaplanowane, $\mathrm{z}$ zestawem celów podstawowych i pośrednich, głównych i ubocznych, strategicznych i taktycznych, z przewidzianymi potrzebami w zakresie zasobów ludzkich, finansowych, materialnych, $\mathrm{z}$ ustalonym harmonogramem czynności, przygotowanymi i opanowanymi metodami działania itd. Zarządzać znaczy: postępować w sposób efektywny, uwzględniający bilans efektów i nakładów, łączący w jedną zintegrowaną całość wszystkie potrzebne i dostępne elementy służące realizacji założonych celów. Jeśli zatem zarządzanie kulturą jest zbiorem działań nastawionych na realizację przyjętych wcześniej celów w sposób maksymalnie efektywny, uwzględniający racjonalne wykorzystanie ludzi, zasobów i metod - to na pewno mieści się ono w obrębie nauk ekonomicznych i menedżerskich.

4 P. Hirsch, D. Levin, Umbrella Advocates Versus Validity Police: A Life-Cycle Model, „Organizational Science” 1999, Vol. 10, No. 2, s. 200-203, [cyt. za:] G.F. Lowe, Introduction: What's So Special About Media Management, [w:] Managing Media Firms and Industries. What's So Special About Media Management, red. G.F. Lowe, Ch. Brown, New York - Dordrecht - London 2016, s. 3-4. 
Podobnie wypowiedziała się dr Anna Janowska (SGH w Warszawie), która wskazała, że zarządzanie kulturą należy:

do szeroko rozumianych nauk ekonomicznych (nauk o zarządzaniu), dlatego że używane są tu metody i modele specyficzne dla tych nauk. Wyjątkowy jest przedmiot - kultura, co stawia całe zagadnienie trochę pomiędzy dyscyplinami. Trzeba bowiem znać specyfikę funkcjonowania sektorów kultury, aby nimi właściwie zarządzać, np. wiedzieć, na czym polega proces twórczy, praca artystów, co wyróżnia produkty kultury spośród innych produktów itd.

Badaczka zwróciła także uwagę na trzy specyficzne aspekty zarządzania kulturą:

1. Praca twórcza oraz produkcja dóbr kultury nie podlegają niektórym prawom ekonomicznym, np. nie sprawdza się prawo malejącej użyteczności krańcowej, działa efekt Baumola 5 .

2. Bardzo ważną rolę odgrywają tutaj efekty zewnętrzne, wpływające na budowanie kapitału kulturowego oraz społecznego ludzi, a także na ogólny dobrobyt. Dlatego zarządzania kulturą nie należy prowadzić tak, jak zarządzania jakąkolwiek działalnością biznesową, komercyjną.

3. Artyści pracują inaczej niż pracownicy pozostałych sektorów gospodarki, ważne są tutaj: proces twórczy i jego efekt, kwestia czasu pracy i czasu wolnego, wynagrodzenia za pracę itd.

Do specyfiki zarządzania zasobami ludzkim w sektorach kultury nawiązał także Łukasz Wróblewski:

${ }^{5}$ Badaczka powołuje się w tym miejscu na słynną pracę Williama Baumola i Williama Bowena Performing Arts: The Economic Dilemma, która ukazała się w 1966 roku i trwale zmieniła stosunek ekonomistów do kultury. Rezultatem badań autorów nad teatrami było m.in. odkrycie tak zwanego efektu Baumola, inaczej nazywanego „chorobą kosztów”. Efekt ten podważa klasyczną tezę ekonomiczną, zgodnie z którą poziom dochodów warunkowany jest produktywnością określonej branży. W przypadku branż kulturalnych postęp technologiczny nie prowadzi do wzrostu produktywności, czyli spadku kosztów. Płace i koszty rosną tam szybciej niż wydajność, co musi prowadzić do deficytu. Produktywność teatru pozostaje bowiem na podobnym poziomie (przyp. red.). 
Jeszcze kilkadziesiąt lat temu wielki talent i mistrzowska sztuka stawiały wielu artystów występujących na scenie jak gdyby ponad prawami obowiązującymi ludzi innych profesji. Przywileje te artyści często wykorzystywali, tyranizując niemiłosiernie dyrekcje filharmonii, teatrów operowych, teatrów dramatycznych, impresariów, a nawet i twórców sztuki. Mimo że w XXI wieku sytuacja diametralnie się zmieniła, to jednak współpraca $\mathrm{z}$ artystami ciągle zasadniczo różni się od pracy z ludźmi wszystkich innych profesji. Jak twierdzi R. Bing ${ }^{6}$, pracownicy administracyjni też niewątpliwie mają swoje ambicje, ale nie muszą co dzień rzucać wszystkiego na szalę, co wieczór walczyć o swoją egzystencję. Dlatego też artyści to ludzie wyjątkowi wrażliwi i drażliwi, nerwowi i cokolwiek zwariowani.

Do zarządzania zasobami ludzkimi odniosła się także Katarzyna Plebańczyk, której zdaniem: „zarządzanie kulturą mieści się w nurcie zarządzania w naukach humanistycznych, co oznacza, że skupia się na zarządzaniu ludźmi, przez ludzi i dla ludzi”. Łukasz Wróblewski wskazał natomiast, że:

Zarządzanie w kulturze ma oczywiście wiele cech wspólnych z tym, które wykształciło się w przedsiębiorstwach, ale wiele też takich, które spotykamy tylko w sektorze kultury. Jest to widoczne chociażby w działaniach marketingowych instytucji kultury, które ze względu na bardzo specyficzny produkt przybierają dużo oryginalnych cech. Dla przykładu, cena w organizacjach biznesowych jest jednym $\mathrm{z}$ najbardziej elastycznych instrumentów marketingu mix $^{7}$, a jej kształtowanie dzisiaj nie nastręcza menedżerom zbyt wielu problemów - w przeciwieństwie od rynku dóbr i usług kultury, gdzie cena jest jednym z najtrudniejszych do ustalenia składników marketingu. Trudność sprawia ustalenie ogólnych zasad, na podstawie których ustalano by ceny na usługi kultury. Duże zróżnicowanie usług, konkurencja oraz różnorodne uregulowania zewnętrzne (chociażby zapisy mówiące o powszechnym dostępie do kultury) ograniczają swobodę w kreowaniu strategii cenowej.

${ }^{6}$ R. Bing, 5000 wieczorów w operze, tłum. W. Kalinowski, Warszawa 1982, s. 34-35.

7 Marketing mix to zespół instrumentów służących do oddziaływania na rynek. To popularna kompozycja teoretyczna związana z marketingiem. Składa się z czterech elementów: ceny, produkcji, miejsca i promocji (przyp. red.). 
Na odmienność zarządzania kulturą zwróciła także uwagę Urszula Grzelońska, podkreślając różnicę między pracą w „zwykłej” gospodarce a pracą w kulturze, pracą artystów:

Jednym z głównych zadań w zarządzaniu firmą wytwarzająca rzeczy powtarzalne jest wypracowanie w ludziach motywacji, która pozwoli im wykonywać setki powtarzalnych czynności, nie umierając przy tym ze znudzenia. W ludziach pracujących twórczo, a taka jest praca w kulturze, nie trzeba budować takiej motywacji, oni ją mają wrodzoną! Zawsze znajdzie się mnóstwo ludzi, którzy z entuzjazmem będą tworzyć. W kulturze widzianej oczami ekonomisty i zarządzającego nie ma problemu z podażą. Jest natomiast problem z popytem na wytwory twórców, na dobra kultury. Dlatego marketing dóbr kultury wymaga gruntownego wzmocnienia w porównaniu z marketingiem powtarzalnych przedmiotów i usług, których użyteczność nie budzi na ogół niczyich wątpliwości.

Badaczka dostrzega ponadto różnicę w skali wytwórstwa zwykłych dóbr i dóbr kultury:

Gdy szuka się rynku dla miliona słoików kawy, w cenie jednego słoika łatwo zmieścić dziesięć groszy na marketing, który wymaga nakładów finansowych w kwocie stu tysięcy złotych. Przedstawienie teatralne robi się dla powiedzmy - dwudziestu tysięcy osób, i uzyskanie stu tysięcy złotych na marketing tegoż przedstawienia wymagałoby zmieszczenia pięciu złotych w cenie biletu, a o to już trudniej.

Dr Patrycja Klimas (UE w Katowicach), która uznaje zarządzanie kulturą za obszar nauk o zarządzaniu, stwierdza ponadto, że:

Na tle innych obszarów zarządzania [zarządzanie kulturą - przyp. red.] wyróżnia się np. znacznym udziałem kapitału publicznego (co wpływa na konkurencyjność), koniecznością rozpatrzenia nie tylko płatnych, ale także bezpłatnych modeli biznesu, ponadprzeciętną rolą zarządzania projektami, deficytem wyspecjalizowanej kadry menadżerskiej.

Prof. Dorota Ilczuk (Uniwersytet SWPS), której habilitacja, jak sama przyznaje, jako pierwsza w Polsce usytuowana była w nurcie zarządzania w naukach humanistycznych, uważa, iż: 
Absolwent wyłącznie ogólnego zarządzania zazwyczaj jest beznadziejnym menedżerem kultury, słabo rozumiejącym specyfikę zarządzania w tym obszarze. [...] Jeśli oficjalnie został w nauce wydzielony taki nurt zarządzania, oznacza to, że zarządzanie w kulturze wymaga innych kompetencji, odmiennych sposobów przekazywania wiedzy. Różni się więc od zarządzania wykładanego na wydziałach ekonomicznych szkół wyższych.

Obecnie w Polsce nauki o zarządzaniu stanowią dyscyplinę naukową w zakresie dwóch dziedzin - nauk ekonomicznych, ale także nauk humanistycznych (na Uniwersytecie Jagiellońskim). Wedle wcześniej obowiązującej klasyfikacji zarządzanie należało wyłącznie do nauk ekonomicznych. Oznacza to, być może, że od pytania o miejsce zarządzania kulturą w obszarze kulturoznawstwa właściwsze byłoby pytanie szersze - o to, jakie aspekty zarządzania kulturą sytuują je w obszarze nauk humanistycznych.

Do specyfiki zarządzania kulturą nawiązał Tadeusz Stryjakiewicz, który stwierdził, że:

[jego] wyróżnikiem jest dualny charakter procesu zarządzania kulturą, związany z jednej strony z jego wymiarem ekonomicznym (gdzie z powodzeniem można wprowadzać rozwiązania oparte na ekonomicznych teoriach zarządzania), z drugiej - z wymiarem humanistycznym i społecznym (gdzie wiele działań, np. sam proces tworzenia, $z$ trudem poddaje się „zarządzaniu”).

Krzysztof Stachowiak również zwrócił uwagę na cechujący zarządzanie kulturą dualizm ekonomiczno-kulturowy, co oznacza, że badane zjawiska przejawiają, w zależności od sytuacji, własności ekonomiczne lub kulturowe.

Ma to doniosłe konsekwencje metodologiczne i wskazuje na interdyscyplinarność tej dziedziny wiedzy. Wynika to ze specyfiki przedmiotu tego zarządzania, czyli kultury. Procesy ekonomiczne i kulturowe mają odmienną naturę. Zarządzanie kulturą (oraz nauka o nim) z jednej strony zakorzenione jest w teoriach zarządzania, a $\mathrm{z}$ drugiej - powinno uwzględniać specyfikę działalności kulturalnej (np. muzeów, teatrów, galerii sztuki) oraz wytworów kultury. Styk procesów kulturowych i ekonomicznych sprawia, że zjawiska będące przedmiotem zainteresowania zarządzania kulturą mają dualny charakter. [...] Zarządzanie kulturą musi uwzględniać tę dwoistość. W przeciwnym razie kierowanie organizacjami kultury nie będzie efektywne. Nauka o zarządzaniu kulturą również musi brać to pod uwagę, ponieważ bez tego obraz badanych zjawisk będzie niepełny lub niewłaściwy. 
W naukach o zarządzaniu wyróżnia się dwadzieścia jeden subdyscyplin. Biorąc pod uwagę kryterium typów organizacji, można wyróżnić zarządzanie organizacjami gospodarczymi oraz zarządzanie publiczne i $\mathrm{NGO}^{8}$. Druga z subdyscyplin została wyodrębniona właśnie ze względu na specyfikę zarządzania organizacjami publicznymi. Prof. Alina Kozarkiewicz (AGH) stwierdziła, że:

Trudno wskazać metody lub modele zarządzania, które nie mogą być stosowane w zarządzaniu kulturą, zwłaszcza że zarządzanie kulturą to zarządzanie w sferze publicznej (zarządzanie publiczne), ale także zarządzanie w organizacjach komercyjnych, działających w oparciu o finansowanie przez udziałowców (prywatnych właścicieli, a czasami samych twórców czy też przez akcjonariuszy).

Iwona Haberny (Agencja Promocyjna OKO) dzieli zarządzanie kulturą na dwa nurty:

1. Zarządzanie „przemysłami kreatywnymi”, czyli tym, co w zamierzeniu ma przynosić zysk: I tutaj mają zastosowanie normalne zasady rynkowe i system zarządzania (a także marketingu i promocji) obowiązujące w każdym innym biznesie. Łącznie z tym, że wartości artystyczne często ustępują wobec zysku - rynek bestsellerów (książka, film, muzyka) miewa niewiele wspólnego z prawdziwą sztuka i kulturą. Potrzebny jest dobry, utalentowany manager (może być - a nawet lepiej, gdy jest - zupełnie niezwiązany z kulturą), który potrafi zatrudnić odpowiednie osoby i bez emocji zarządzać nimi i całą firma.

2. Zarządzanie instytucjami kultury: w tym wypadku chodzi nie o zysk, ale o stworzenie warunków, w których kultura (twórcy i ich publiczność) może się najpełniej rozwijać. [...] Potrzebna jest tu osobna refleksja teoretyczna, która pozwoli ustalić priorytety, kryteria i długofalowe cele. Natomiast wdrażanie tego wymaga otwarcia się na wiedzę już wypracowaną (zarządzanie, marketing, promocja - tutaj nie widzę powodu, by wyważać otwarte drzwi i tworzyć nowe teorie na potrzeby kultury).

8 S. Cyfert, W. Dyduch, D. Latusek-Jurczak, J. Niemczyk, A. Sopińska, Subdyscypliny w naukach o zarządzaniu - logika wyodrębniania, identyfikacja modelu koncepcyjnego oraz zawartość tematyczna, „Organizacja i Kierowanie” 2014, nr 1(161), s. 40. 
Podobnie sprawę przedstawia też prof. Piotr Majewski (UKSW, Dyrektor Instytutu Muzealnictwa i Ochrony Zbiorów).

Zgodnie z przytoczonym wcześniej podziałem na subdyscypliny w naukach o zarządzaniu, zarządzanie kulturą znajduje się zarówno w obszarze zarządzania organizacjami gospodarczym (np. zarządzanie teatrami działającymi na zasadach komercyjnych), jak i w obszarze zarządzania publicznego i NGO (np. działania instytucji kultury finansowanych publicznie). Kwestią otwartą pozostaje pytanie, czy nie uprawnia to do wydzielenia oddzielnej subdyscypliny w naukach o zarządzaniu, jaką byłoby zarządzanie w kulturze?

Większość ekspertów wskazała, że modele i metody zarządzania stosowane w organizacjach gospodarczych są i mogą być wykorzystywane w zarządzaniu kulturą, ale powinny zostać dostosowane do specyfikacji organizacji z sektorów kultury. Dr Mateusz Lewandowski (UJ) stwierdził, że:

$\mathrm{W}$ pierwszej kolejności należy stosować modele zarządzania w organizacjach biznesowych dla tych podmiotów, które w kulturze działają czysto komercyjnie, a modele zarządzania publicznego dla podmiotów sektora publicznego, a więc instytucji kultury. Analogicznie w przypadku organizacji pozarządowych. Kluczowe jest jednak działanie w ramach tak zwanego współrządzenia (governance) i szukanie rozwiązań hybrydowych oraz wypracowywanie metod dedykowanych sektorowi kultury.

Łukasz Wróblewski wskazał, że „zarządzanie w kulturze wymaga spojrzenia holistycznego. Wymaga rozwiązań, metod oraz narzędzi badawczych bardziej wyrafinowanych niż te, które dają odpowiedzi wyłącznie zerojedynkowe”. Mateusz Lewandowski zwrócił natomiast uwagę, iż:

Kluczowe jest zachowanie zdrowego rozsądku i krytycznego myślenia $\mathrm{w}$ dostosowywaniu: czasem oznacza to wprowadzenie kosmetycznych zmian, a czasem daleko idących modyfikacji. Nie zawsze dostosowanie modelu i metod zarządzania przełoży się na oczekiwane rezultaty i ma sens. Przykładowo, zarządzanie jakością i ISO ${ }^{9}$ sprawdzi się bardziej w bibliotece niż w teatrze, ale czy konkretna biblioteka jest gotowa do poniesienia

${ }^{9}$ ISO - termin z zakresu zarządzania jakością. Normy z rodziny ISO 9000 dotyczą zarządzania jakością, czyli podejmowania działań z zakresu kierowania organizacją i nadzorowania jakością w organizacji (przyp. red.). 
nakładów na wdrożenie takiego rozwiązania i czy będzie w stanie skonsumować rezultaty tej metody, to osobna kwestia.

Maciej Dominiak (menedżer kultury współpracujący z UKSW) podkreślił jednak, iż:

Teoria zarządzania jest uniwersalna, w podstawowych aspektach opiera się po prostu na zasadach ludzkiej percepcji, ludzkich emocji, elementarnych regułach porządkujących otaczającą nas rzeczywistość. Specyfika zarządzania w kulturze polega na „przetworzeniu” teorii zarządzania w sposób uwzględniający specyfikę i unikalność działalności kulturalnej, specyfikę i unikalność „produktów kultury” oraz specyfikę potrzeb odbiorców. Jeśli przeanalizujemy np. zagadnienia związane $\mathrm{z}$ teorią zarządzania zespołem ludzkim, to fundament teoretyczny pozostanie ten sam, ale na poziomie szczegółowym teoria będzie wymagała precyzyjnego dostosowania do specyfiki branży artystycznej i całej bogatej sfery złożonych relacji, np. na linii "pion artystyczny” - „pion organizacyjny”, w przypadku których „standardowe" teorie zarządzania nie znajdą zastosowania”.

Paweł Płoski (Teatr Narodowy w Warszawie) słusznie więc zauważył, że:

Należy zwrócić uwagę na sposoby dostosowywania tychże [modeli i metod przyp. red.] do interesującego nas obszaru. Dostosowywanie powinno odbywać się z poszanowaniem, ale przede wszystkim zrozumieniem obszaru, do którego mają być „aplikowane”. Pamiętam kursy zarządzania kryzysowego w kulturze, gdzie przykładem kryzysu było reagowanie na złą recenzję po przedstawieniu. Trenerka zdaje się nigdy w teatrze nie pracowała, więc wymyśliła przykład „na sucho”. Nie muszę dodawać, jaką wartość przedstawiało to ćwiczenie. (Wszelkie znane mi próby reagowania na tego typu teksty kończyły się porażką instytucji i „moralnym zwycięstwem” krytyka). Zatem w zarządzaniu kulturą dobrze jest pilnować się, by nowa metoda stanowiła pomoc we wskazywaniu i rozwiązywaniu problemów, a nie skrywaniu ich pod "profesjonalnym nazewnictwem”.

Podobnie wypowiedział się także Mieczysław Morawski, który stwierdził, że po dokonaniu potrzebnych dopasowań nie ma:

przeszkód w stosowaniu rozwiązań menedżerskich w działalności teatralnej, filmowej, wystawienniczej, festiwalowej czy muzealnej. W każdej organizacji 
i przedsięwzięciu liczy się racjonalne podejście do finansów, organizacji pracy, zatrudnienia, marketingu, logistyki. Konieczna jest strategia i ustalony model działania (biznesu). Po drugiej stronie jest wymagający, coraz bardziej obyty, dobrze poinformowany, wykształcony i często wrażliwy klient, który oczekuje doznań i przeżyć wyjątkowych; nawet jeśli ulotnych, to do głębi poruszających. Tenże klient oczekuje jednakże, iż wartości artystyczne otrzyma w rozsądnej cenie, w komfortowych warunkach, na najwyższym poziomie profesjonalnej sztuki, wcześniej łatwo się o ich miejscu i czasie ekspozycji dowiadując i odpowiednio łatwo rezerwując i płacąc na przyszłe doznania.

Katarzyna Plebańczyk dodała, że w zarządzaniu kulturą używa się:

instrumentów i narzędzi charakterystycznych dla zarządzania w ogóle, ale w zależności od formy prowadzonej działalności jedne będą wykorzystywane intensywniej bądź zostaną zaadaptowane. Dobrym przykładem jest tu dobór narzędzi i instrumentów zarządzania w kontekście celów działalności. Każda instytucja/organizacja przeprowadzi kalkulację zysków i strat, ale np. teatr publiczny zdefiniuje je w innych kategoriach niż wydawnictwo. Dla teatru ważniejszy będzie zysk niematerialny (choć finansowy jest nie bez znaczenia), rozwój artystyczny, szansa promocji zespołu, artystów czy wpisanie się w modny ostatnio w Polsce audience development. Dla wydawnictwa istotny jest zysk finansowy, ale w zależności od profilu firmy - także dbanie o wizerunek. Wydaje się, że aspekt humanistyczny (przez ludzi i dla ludzi) ma tu znaczenie największe i jest czynnikiem odróżniającym [zarządzanie kulturą - przyp. red.] od zarządzania ekonomicznego, nastawionego na zysk, najczęściej rozumiany w kategoriach finansowych.

\section{PRZYNALEŻNOŚĆ DO KULTUROZNAWSTWA?}

Wśród ankietowanych ekspertów znacznie mniej było tych, którzy uznali, że zarządzanie kulturą przynależy do kulturoznawstwa. Piotr Majewski stwierdził, iż:

Bez wątpienia sfera „ekonomii” jest przedmiotem zarządzania. Zarządzanie, tak w wymiarze instytucjonalnym, jak również indywidualnym, ma swoje konsekwencje, by tak rzecz, „kosztotwórcze”. Świadomość faktu, iż nasze wybory, nasze decyzje przybierają także formę excelowych tabel z kosztorysem, jest rudymentem, zwłaszcza praktycznego parania się zarządzaniem. 
Kto nie ma poczucia odpowiedzialności za pieniądz publiczny, kto nie ma wiedzy - a przynajmniej potrzeby jej zdobycia - na temat zamówień publicznych czy podatku VAT, niech nie ryzykuje losów powierzonej mu instytucji i ludzi, zostając jej szefem. Z pewnością więc nauki ekonomiczne są ważnym aspektem zarządzania kulturą. Ale właśnie w takim porządku, nie na odwrót. „Budżetowanie” nie jest bowiem celem samym w sobie; ono jest ramą dla realizacji misji czy zadań statutowych, na które składają się poszczególne projekty uszeregowane w długo-, średnio- i krótkoterminowe szeregi „strategii” i „polityk”. Zarządzanie, zwłaszcza w instytucjach kultury, to myślenie o celach, myślenie o zmianie, to ambicja kreowania i inspirowania ludzkich postaw i zachowań w skali społecznej; to działalność twórcza, która, jeśli mówimy o aspektach finansowych, musi zawierać w sobie prawo do błędu i prawo do autokorekty (co w żadnym stopniu nie oznacza przyzwolenia na intencjonalne omijanie prawa).

W związku z tym badacz (a jednocześnie praktyk, szef instytucji kultury) lokuje zarządzanie kulturą w dyscyplinarnych ramach kulturoznawstwa:

Na tym rozdrożu nauk i wartości, gdzie podążać można w jednym kierunku, nie gubiąc innych, korzystając z bogactwa synergii i interdyscyplinarności, pozostając otwartym na spełnienie intelektualne, twórcze, niekoniecznie „ekonomiczne”. Bo zarówno zarządzanie kulturą, jak i sama kultura to kategorie non profit, nie zaś nastawione na zysk; choć liczą się z „groszem”, nie stawiają go w centrum świata wartości.

\section{ZARZĄDZANIE KULTURA JAKO OBSZAR INTERDYSCYPLINARNY}

Część respondentów wskazała, że zarządzanie kulturą nie należy ani do nauk o zarządzaniu, ani do kulturoznawstwa. Dobrze obrazuje to opinia dra hab. Marcina Adamczaka (UAM), który uważa, że „czasy współczesne są okresem zacierania granic między dyscyplinami, nie podjąłbym się zatem próby określania tutaj wyraźnej przynależności”. K. Klejsa stwierdził natomiast, że: „Zarządzanie kulturą z pewnością nie jest osobną dyscypliną, tak jak nie jest nią, powiedzmy, historia filmu polskiego. Powiedziałbym, iż zarządzanie kulturą to interdyscyplinarne studia humanistyczno-ekonomiczne". Koresponduje to z uwagą Macieja Dominiaka: 
Zarządzanie kulturą traktowałbym raczej jako pewnego rodzaju metadyscyplinę, wykorzystującą zarówno elementy nauk ekonomicznych (w kontekście aspektów finansowo-administracyjnych), humanistycznych (stanowiących w procesie zarządzania przedmiot realizowanych działań - np. poszczególne dziedziny sztuki), jak i nauk technicznych (np. działania związane z koordynacją techniczną, posługiwaniem się nowymi technologiami itp.). Myślę, że wspomniana powyżej multidyscyplinarność sprawia, że dziedzina ta bazuje na dokonaniach innych dyscyplin nauki, czerpie z ich podstaw teoretycznych i przetwarza wiedzę na potrzeby procesu zarządzania przedsięwzięciami kulturalnymi, uwzględniając ich specyfikę i unikalność.

Podobnie wypowiada się mgr Joanna Śmietanka (UWR):

Zarządzanie kulturą, jako przynależną do obszaru nauk humanistycznych dziedzinę interdyscyplinarną, umiejscawiać należy w obrębie nauki o zarządzaniu, z elementami kulturoznawstwa, literaturoznawstwa, historii sztuki, a także nauk społecznych, takich jak nauka o mediach, nauka o poznaniu i komunikacji, psychologia czy socjologia (jeśli wliczymy w to zarządzanie w obrębie socjologii kultury, obejmujące zarządzanie relacjami pomiędzy społeczeństwem a kulturą). Wśród zagadnień związanych z zarządzaniem kulturą odnaleźć można również zagadnienia z zakresu prawa (np. w przypadku imprez masowych ${ }^{10}$ ), dziedzin nauk filmowych, sztuk plastycznych, muzycznych oraz teatralnych. Interdyscyplinarne podejście do zarządzania kulturą pozwala na wykorzystanie wiedzy z innych dziedzin, która wydaje się niezbędna do prawidłowego rozumienia mechanizmów zachodzących w managemencie kultury. Mowa tu głównie o kulturoznawstwie, nauce o mediach, nauce o poznaniu i komunikacji, a także psychologii.

Alina Kozarkiewicz widzi specyfikę zarządzania kulturą w wielowymiarowości i interdyscyplinarności. Interdyscyplinarność wyraża się w badaniach na styku nauk ekonomicznych, humanistycznych i społecznych: ekonomii, nauk o zarządzaniu, socjologii, filozofii i kulturoznawstwa. Natomiast wielowymiarowość polega na kompleksowości tematyki badawczej i wielości paradygmatów charakterystycznych dla nauk społecznych.

10 Ustawa o bezpieczeństwie imprez masowych z 2009 roku oraz Ustawa z dnia 11 września 2015 roku o zmianie Ustawy o bezpieczeństwie imprez masowych oraz niektórych innych ustaw. 


\section{Mateusz Lewandowski uważa, że:}

Każda sfera działalności kulturalnej ma swoją specyfikę, która determinuje metody i modele zarządzania. Na przykład galerie działające na rynku sztuki, biblioteki, agencje eventowe, muzea, domy kultury i opery - wszystko to są zupełnie różne byty. Ich specyfika wymaga szczegółowej wiedzy, która w zarządzaniu kulturą nie jest podawana studentom. Ponadto ważne są kontakty w środowisku - to jest bariera dla studentów, którzy chcą działać, a nie mogą, chyba że sami mają takie kontakty. Reasumując, uważam, że większa specjalizacja jest istotna dla rozwoju zarządzania kulturą.

Podobnie wypowiedziała się dr Marzenna Wiśniewska (UMK), która wskazała, że „zarządzanie kulturą, osadzone głównie w naukach humanistycznych i społecznych, stanowi dobrą platformę do wymiany badawczej $\mathrm{z}$ reprezentantami nauk ścisłych/technicznych, np. w zakresie informatyki - perspektywa ta cały czas wydaje się jeszcze mało zagospodarowana”. Krzysztof Stachowiak również zwrócił uwagę na multidyscyplinarny charakter zarządzania kulturą:

Składają się nie przede wszystkim badania: ekonomiczne (zwłaszcza z obszaru nauki o zarządzaniu, ale także ekonomii oraz finansów), kulturoznawcze, socjologiczne, filozoficzne, związane ze sztuką (estetyka); ale nie brak także szeregu innych dyscyplin. Multidyscyplinarność (wielodyscyplinarność) występuje wtedy, gdy pole badawcze zawiera pewną sumę składników różnych dyscyplin, które zachowują swoją indywidualność. Nauka o zarządzaniu kulturą nie nabrała jeszcze interdyscyplinarnego charakteru, a z całą pewnością nie stanowi odrębnej dyscypliny. Interdyscyplinarność stanowi bowiem wyższy poziom multidyscyplinarności, na którym różne dyscypliny dążą do uzyskania zintegrowanego ujęcia i wyników, które nie będą już tylko sumą poszczególnych rezultatów.

W zarządzaniu kulturą sięga się po dorobek wielu różnych nauk i dyscyplin naukowych. Tym samym trudno jest jednoznacznie przypisać zarządzanie kulturą do określonego obszaru. Można odnieść wrażenie, że to, co najciekawsze, powstaje na styku wielu różnych obszarów badawczych, a nie w ramach sztywno określonych specjalizacji. Sprawia to, że w zarządzaniu kulturą powinniśmy sięgać do dorobku różnych dyscyplin, aby dążyć do powstania interdyscyplinarnego obszaru badawczego, w ramach którego 
badania będą prowadzone przez naukowców z różnych specjalizacji. Warto w tej sytuacji przy toczyć wypowiedź Marzenny Wiśniewskiej, która zwróciła uwagę, że „jedną ze znamiennych tendencji we współczesnych badaniach naukowych jest przekraczanie granic między dyscyplinami, co skutkuje zarówno poszerzaniem ujęć metodologicznych, jak i tworzeniem interdyscyplinarnych zespołów badawczych”. Jak wynika z naszych doświadczeń, a także z wyników ankiety, zarządzenie kulturą zarówno w praktyce, jak i badaniach w największym stopniu sięga do dorobku z zakresu szeroko rozumianej teorii zarządzania. Jest to zgodne z opinią Macieja Dominiaka, który zauważył, iż:

Zarządzanie kulturą to w sensie ogólnym wciąż element dziedziny zwanej zarządzaniem, z tą różnicą, że uwzględniający specyfikę unikalnej materii, jaką jest kultura, uwzględniający jej „niemierzalność”, pozaekonomiczne walory i czynniki, które budują wartość kultury w oparciu o zupełnie inne wskaźniki niż np. w standardowym obiegu komercyjnym, bazującym na wyprodukowaniu prostego produktu zaspokajającego proste potrzeby klienta.

\section{„BIAŁE PLAMY”}

Szczególnie istotne w kontekście celów niniejszej ankiety było pytanie o to, który obszar zarządzania kulturą należy rozwinąć: obszar przedmiotowy (np. teorię zarządzania, zarządzanie strategiczne, zarządzanie kapitałem ludzkim, przywództwo, marketing i inne) czy obszar podmiotowy (np. sektory kreatywne, sektory kultury, rynek audiowizualny, teatry i inne). Tu odpowiedzi się powtarzają - poniżej prezentujemy tylko wybrane z nich i jak łatwo zauważyć, wyczuwa się deficyt w obu omawianych obszarach.

Tadeusz Stryjakiewicz uważa, że:

W obszarze przedmiotowym należy przede wszystkim zdefiniować specyfikę zarządzania kulturą w kontekście dotychczasowego dorobku nauk o zarządzaniu i kulturoznawstwa oraz wskazać „luki poznawcze”. Natomiast w obszarze podmiotowym wielkim wyzwaniem wydają się te segmenty kultury, na które najsilniej wpływają przemiany związane z nowymi technologiami informacyjno-komunikacyjnymi (ICT), np. miejsce bibliotek w dobie rozpowszechniania się e-booków, rynek audiowizualny itp. 
Dr Kamila Lewandowska (Akademia Teatralna im. Aleksandra Zelwerowicza w Warszawie) natomiast stwierdza, iż:

Powinniśmy zacząć od pytania: czym ma zajmować się obszar nauk zwany zarządzaniem kulturą? Większość publikacji dostępnych na polskim rynku podchodzi do tematu przez pryzmat zarządzania instytucjami. Autorzy bazują na schematach zarządzania strategicznego (misja/wizja/cele strategiczne - analiza SWOT - plany strategiczne itp.). Moim zdaniem są to schematy już mocno przestarzałe i warto by poszukać nowych rozwiązań. Przede wszystkim należy uwzględnić to, że większość praktyków kultury nie jest i nigdy nie będzie dyrektorami instytucji. Rozwój wiedzy o zarządzaniu instytucjami jest na pewno potrzebny, np. należałoby poświęcić więcej uwagi komunikacji wewnętrznej w organizacjach. A jednak na największy deficyt wiedzy mogą obecnie narzekać pracownicy bardziej „elastycznych” form działalności kulturalnej, takich jak małe teatry niepubliczne, niezależne zespoły itp.

„Zdecydowanie należałoby rozwinąć obszary z zakresu zarządzania strategicznego - mam tu na myśli przede wszystkim wdrożenie modelowych procesów zarządzania, które umożliwią osiąganie przez ośrodki kultury swoich celów w sposób skuteczny i efektywny" - stwierdza Joanna Śmietanka. Piotr Majewski z kolei uważa, iż:

Ze wskazanego obszaru [przedmiotowego - przyp. red.] rozwinięcia wymaga przede wszystkim zarządzanie strategiczne. Pytanie o strategię to pytanie o cel: w wymiarze wspólnotowym, indywidualnym, państwowym, instytucjonalnym etc. To pytanie o udzielenie odpowiedzi, która nie może być obciążona detalem (wszak większość z tych detali zmienna jest i nieprzewidywalna...). Pytanie o strategię to odpowiedź na potrzebę i umiejętność formułowania rudymentarnych założeń, które w sposób naturalny „toną” w codzienności krótkoterminowych wyzwań, okiełznanych przymusem „responsywności” ludzi itd. Zarządzanie strategiczne to także umiejętność zerwania tych pęt.

„Warto rozwijać zarządzanie strategiczne, zarządzanie kapitałem ludzkim, ale też - co mocno podkreślamy - komunikację wartości” - stwierdzili eksperci związani z instytucją kultury Zamek Cieszyn. „Zarówno naukowcy, jak i przedstawiciele praktyki są zgodni, że należy dążyć do adaptacji metod i technik zarządzania na potrzeby różnych podmiotów sektora kultury, 
$\mathrm{w}$ tym również publicznych instytucji kultury. W tym kontekście jedną z ważniejszych koncepcji zarządzania w kulturze jest zarządzanie strategiczne, gdzie stan wiedzy ciągle jest jeszcze niepełny” - podkreśla Łukasz Wróblewski, i dodaje:

Luka ta jest widoczna między innymi w kluczowej sferze zarządzania strategicznego, jaką jest marketing strategiczny, a w konsekwencji ma przełożenie na jedno z najważniejszych narzędzi marketingu strategicznego, czyli na strategię marketingową. Dotyczy ona [luka - przyp. red.] chociażby procedur wdrażania strategii marketingowej oraz metod pomiaru, które umożliwiłyby skuteczną kontrolę jej realizacji w podmiotach kultury. W związku $\mathrm{z}$ tym faktem $\mathrm{w}$ polskich podmiotach sektora kultury obserwuje się problem zarówno o charakterze teoretycznym, jak i metodycznym, związany z określeniem stopnia i zakresu wdrożenia strategii marketingowej czy odpowiednią procedurą umożliwiającą przeprowadzenie kontroli jej realizacji. Wynika to głównie z faktu, że dotychczasowe badania, dotyczące strategii marketingowych instytucji kultury w Polsce, koncentrują się na pewnych ich elementach czy procedurach, jak np. identyfikacja potrzeb, preferencji i zachowań konsumentów na rynku dóbr i usług kultury, segmentacja rynku, strategiczne planowanie marketingowe, możliwości wykorzystania strategii marketingowych, analizy działań marketingowych czy też stopnia ich intensywności i częstotliwości. Bardzo rzadko podnoszony jest natomiast problem dotyczący stopnia i zakresu wdrożenia strategii marketingowej, procedur kontroli realizacji strategii czy głównych problemów jej implementacji.

\section{Joanna Śmietanka wskazuje jednak, iż:}

W obszarze marketingu chyba już wszystko zostało powiedziane, chociaż przydatne wydaje się opracowanie i wdrożenie nowoczesnych technik promocji do ośrodków kulturalnych „starej daty”. Można odnieść wrażenie, że tylko część projektów, jak np. eventy muzyczne, czerpie z dostępnego dziś całego wachlarza metod dotarcia do widza. W tyle wciąż pozostają muzea, filharmonie i wiele innych ośrodków kulturalnych.

Wiele uwagi badacze i eksperci poświęcają zagadnieniom związanym z managementem, zarządzaniem zasobami ludzkimi, kształceniem menedżerów, liderów itd. Dorota Ilczuk uważa, iż w sferze dydaktyki należy zwrócić większą uwagę na psychologiczne uwarunkowania menedżerów, 
na możliwości wykorzystania psychologii i psychologii społecznej do nauki skutecznego zarządzania:

Peter Drucker [jeden z najważniejszych teoretyków zarządzania XX wieku przyp. red.] powtarzał zawsze, że w zarządzaniu najważniejsi są ludzie. Należałoby więc przyjrzeć się, na ile menedżerowie, zarządcy, agenci, producenci przygotowani są emocjonalnie i psychicznie do wykonywania swoich funkcji. $Z$ drugiej strony, nie ma w tym nic nowego - założenie, że w procesach zarządzania kluczowe funkcje pełnią ludzie, jest jedną z pierwotnych tez tej dziedziny wiedzy. Na stare koncepcje nakładane są często nowe nazwy.

„W jakieś mierze czynnik ludzki powinien odgrywać pierwszorzędne znaczenie ze względu na konieczność działań oryginalnych, pionierskich, często odważnych i dalekowzrocznych” - uważa Mieczysław Morawski. Dlatego też nacisk należy położyć na „zagadnienia związane z przywództwem, kształtowaniem cech liderów kreatywnych zespołów i projektów, problematykę profilu kompetencyjnego osób inicjujących i prowadzących przedsięwzięcia kulturalne, oddziaływanie lidera na współpracowników itd.”.

Piotr Majewski dodaje:

Odwołam się do potrzeb najbliższego mi sektora kultury - sektora muzealnego. Jakkolwiek wzrasta systematycznie oferta kształcenia (w tym uniwersytecka) dla kadry zarządzającej wszystkich szczebli, tak się jednak składa (tu polecam prześledzenie karier zawodowych osób „sprawujących władzę” w polskim muzealnictwie), że większość dyrektorów (i coraz więcej dyrektorek) to swoiste „samorodki”, ludzie budujący swą zawodową pozycję przez drogi (a czasem bezdroża) praktyki, z ciągle zbyt małą podbudową teoretyczną. Moje osobiste doświadczenie ten model potwierdza. Ciągle w Polsce jeszcze zbyt często najpierw się szefem zostaje, a potem do tej roli dopiero dorasta (zwłaszcza w wymiarze wiedzy teoretycznej) albo... nie dorasta. Jest więc ten przeze mnie wskazany obszar podmiotowy ciągle odkrywaną dziedziną.

Alina Kozarkiewicz stwierdza natomiast, że:

Wydaje się, że trudno pominąć którykolwiek z wymienionych powyżej obszarów [przedmiotowy i podmiotowy - przyp. red.]. Inne potencjalnie ważne obszary to zarządzanie projektami - działalność wielu instytucji 
kultury to działalność projektowa. Można uzupełnić listę obszarów i zagadnień o takie istotne aktualnie problemy, jak dostęp do kultury, digitalizacja, kultura w sieci, uczestnictwo w kulturze w czasach zmian demograficznych i różnorodności.

„Ważne są procesy finansowe, jak choćby pozyskiwanie środków finansowych, ich efektywne wykorzystanie, identyfikowanie źródeł - donatorów, sponsorów, kredytodawców - uważa Mieczysław Morawski. - Nie można również pominąć równie kluczowych zagadnień własności intelektualnej i praw autorskich”. Konrad Klejsa dodaje do tego: zamówienia publiczne, prawo pracy i prawo podatkowe. Alina Janowska stwierdza natomiast, że:

Ważne są tutaj aspekty finansowania kultury, szczególnie w otoczeniu cyfrowym (erozja prawa autorskiego), mierzenia efektów działalności kulturalnej (nie tylko komercyjnych, finansowych, ale i pozafinansowych). Istotne są prace nad sytuacją artystów, specyfiką ich zawodu, co wiąże się ze sprawą zabezpieczeń finansowych, statusu na rynku pracy itd. W Polsce wciąż brakuje badań sektorów kreatywnych i sektorów kultury; są to obszary niedoceniane przez „poważnych” badaczy zajmujących się np. rynkami finansowymi czy też tradycyjnymi obszarami gospodarki.

W podobnym tonie wypowiada się Mateusz Lewandowski: „Przekornie powiedziałbym, że [rozwinąć należy - przyp. red.] zarządzanie efektywnością (performance management). Debata nad efektami funkcjonowania podmiotów sektora kultury jest niezwykle ważna i ciągle brakuje dobrych opracowań i sensownych rozwiązań”. W przypadku obszaru podmiotowego badacz wymienia sieci, partnerstwa oraz centra aktywności lokalnej.

„Jeśli chodzi o obszar podmiotowy, brakuje mi pogłębionych analiz sektora audiowizualnego. Stosunkowo wiele badań dotyczy kinematografii, niewiele zaś - telewizji i sektora gier" - stwierdza Konrad Klejsa. Marcin Adamczak dodaje natomiast, że:

Bardzo potrzebne byłyby szeroko zakrojone, a jednocześnie wnikliwe, komparatystyczne badania rynku audiowizualnego i przemysłów kreatywnych w różnych krajach, nie tylko europejskich. W ten sposób można porównać skuteczność poszczególnych architektur instytucjonalnych, systemów 
wsparcia i finansowania oraz ich zależność od otoczenia społecznego, rynkowego i rzeczywistości kulturowej.

Na jeszcze inny, rzadko analizowany obszar wskazał Paweł Płoski: „W obszarze podmiotowym wciąż ogromnym materiałem do zagospodarowania są historyczne ujęcia zarządzania kulturą - przede wszystkim funkcjonowanie instytucji kultury w PRL-u i jego skutki w ich współczesnej pracy”. Dorota Ilczuk z kolei zwróciła uwagę na praktyczny aspekt zarządzania kulturą:

$\mathrm{Z}$ naukowego punktu widzenia najciekawsze jest dla mnie łączenie nauki $\mathrm{z}$ aplikacyjnością. Wiedza nie może być odcięta od rzeczywistości. Lubię wiedzieć, że moja praca przekłada się na rozwiązania praktyczne, tak jak było to $\mathrm{np}$. w przypadku opracowania systemu zasilenia finansowania kultury z Totolotka ${ }^{11}$. Możliwość praktycznego zastosowania badań daje uczucie spełnienia.

Krzysztof Stachowiak ujął temat dość szeroko:

Jeśli przyjmiemy, że nauka o zarządzaniu kulturą jest specjalnością nauk o zarządzaniu, to z pewnością rozwój teorii zarządzania w odniesieniu do kultury powinien być priorytetem. Jeśli przyjąć, że nauka o zarządzaniu kulturą jest pewną wyodrębniającą się dziedziną wiedzy, to kluczowe wydaje się określenie jej specyfiki. Aby stała się ona względnie jednorodną dziedziną wiedzy (lub nawet dyscypliną naukową), powinna zmierzać w kierunku interdyscyplinarności, a potem ewentualnego usamodzielnienia (chodzi o samodzielność metodologiczną, a nie instytucjonalną). [...] W związku z tym należy rozwijać zagadnienia teoretyczne, czerpiąc w pierwszych etapach z już ugruntowanych dyscyplin (np. nauki o zarządzaniu, kulturoznawstwa). Równolegle należałoby próbować określić dziedzinę badań, a także ich zakres przedmiotowy, i rozwijać badania empiryczne. Przykładowo, przedmiotem badań może być sektor kultury rozumiany jako ta część szeroko pojętej kultury, której celem jest generowanie nie tylko wartości kulturowych, ale także wartości ekonomicznych. Przedmiotem mogą być organizacje kultury i procesy w nich zachodzące (np. jak zorganizowana jest

${ }^{11}$ D. Ilczuk odwołuje się do stworzonego z jej udziałem systemu finansowania przedsięwzięć i inwestycji kulturalnych z loterii narodowej. Totalizator Sportowy ma obowiązek przekazywać pewne środki pozyskane $\mathrm{z}$ dopłat do gier na polską kulturę, kierując je do Funduszu Promocji Kultury (przyp. red.). 
działalność kulturalna). Problematyką badawczą może być np. efektywność takich organizacji kulturalnych. To wszystko wymaga pogłębionej refleksji i możliwie szerokiej dyskusji.

\section{KULTUROZNAWSTWO JAKO INSPIRACJA DLA ZARZĄDZANIA KULTURĄ?}

Zadaliśmy naszym respondentom pytanie o to, jakie metody i modele z zakresu kulturoznawstwa mogą mieć zastosowanie w specyficznym obszarze badawczym, jakim jest zarządzanie kulturą. Joanna Śmietanka stwierdziła, iż:

Współczesna refleksja kulturoznawcza rozszerza koncepcję samej kultury, która - poza rozumieniem kultury jako zbioru ludzkich wytworów, zainteresowaniem obszarami kultury wysokiej oraz popularnej - zawiera w sobie również całokształt zwyczajów i norm panujących w danej społeczności, w tym również media, konsumpcjonizm czy zjawiska dnia codziennego, takie jak np. moda. Antropologiczne pojmowanie kultury, zachowania i indywidualne preferencje uczestników kultury, sposoby jej doświadczania, konsumpcja mediów, historia myśli o kulturze, teorie kultury - wszystko to znajduje dziś uzasadnienie w obszarze zarządzania kulturą. Teoria zarządzania kulturą czerpie z badań przedmiotowych związanych z elementami (wytworami) kultury stworzonymi przez człowieka - mogą to być analizy konkretnych ośrodków kultury w celu rozpoznania sytuacji zastanej, i tym samym możliwości proponowania rozwiązań (w formie strategii zarządzania). Zastosowanie znajdują tu obserwacje, wywiady, metody socjometryczne z zakresu wiedzy o muzyce, literaturze, plastyce, filmie, teatrze czy komunikacji.

W podobnym tonie wypowiadają się Konrad Klejsa, który zwraca uwagę na znaczenie wywiadu pogłębionego i historii mówionej, oraz Marzenna Wiśniewska, która przywołuje w tym kontekście antropologię kultury, performatykę czy metody wizualne w badaniach jakościowych. Ponadto Paweł Płoski wyróżnia oryginalne metody badania kultury produkcji rozwinięte przez Marcina Adamczaka oraz badania gdańskich socjologów kultury, którzy pod auspicjami Instytutu Kultury Miejskiej przygotowują kolejne raporty dotyczące szeroko rozumianego uczestnictwa w kulturze. Przywołany powyżej Marcin Adamczak odwołuje się natomiast do badań produkcyjnych rozwijanych przede wszystkim przez Johna T. Caldwella. 


\section{ARCHIPELAGI}

Jako że zarządzanie kulturą, jak to zostało powyżej podkreślone, stanowi wciąż nowy obszar badawczy, zdecydowaliśmy się zadać pytanie, czy można obecnie mówić już o środowisku zarządzania kulturą i o znaczących ośrodkach rozwoju tych studiów.

Paweł Płoski uważa - a jego pogląd zdaje się potwierdzać więcej respondentów - iż współpraca ta, choć istnieje, ma wymiar personalny - opiera się na relacjach, kontaktach, spotkaniach: „Mam wrażenie rozproszenia. Zamiast ośrodków mamy wiele osób. »Żyjemy na archipelagach « - by użyć słów poety". Tadeusz Stryjakiewicz zwrócił natomiast uwagę na lokalny charakter tych kontaktów.

Większość osób, które wzięły udział w ankiecie, zdecydowanie podkreśliła znaczenie budowania środowiska badaczy i nawiązywanie współpracy między nimi, jednocześnie ubolewając nad niewystarczającym stanem rozwinięcia tych relacji.

„Król” jest jeden - Instytut Kultury Uniwersytetu Jagiellońskiego, który od lat wydaje cenione czasopismo „Zarządzanie w Kulturze”. „Przoduje ośrodek krakowski, szkoła zarządzania w kulturze stworzona przez profesora Emila Orzechowskiego. W tym wypadku można mówić o konkretnym środowisku badaczy powiązanych $\mathrm{z}$ ośrodkiem Uniwersytetu Jagiellońskiego” - stwierdza Dorota Ilczuk, a wtóruje jej Paweł Płoski: „Ani w Warszawie, ani w Poznaniu, ani w Gdańsku nie nastąpiło jeszcze takie skonsolidowanie sił, z jakim mamy do czynienia w przypadku Krakowa”. „W skali kraju środowisko badaczy jest zatomizowane. Nie znamy się - mówi Dorota Ilczuk. - Paradoksem jest, że kolegów zajmujących się tą dziedziną spotykałam zazwyczaj na konferencjach zagranicznych. Zrozumiałam wówczas, jak potrzebne jest stworzenie mechanizmu wymiany, wspólnej platformy porozumienia”. Dlatego też w maju 2016 roku Doota Ilczuk zainicjowała utworzenie nieformalnej sieci ekonomistów, teoretyków i praktyków zarządzania kulturą oraz ich przyjaciół. Zainteresowanie tą inicjatywą jest bardzo duże.

Na konieczność poszerzenia sieci współpracy zwrócił uwagę także Piotr Majewski: „Na pewno niewystarczająca jest współpraca między ośrodkami naukowymi a instytucjami kultury jako takimi. A nic przecież tak dobrze nie kształtuje wiedzy o zarządzaniu, jak umiejętne łączenie teorii z praktyką, korzystanie $\mathrm{z}$ wiedzy ludzi, którzy smak praktyki poznali, często 
odkrywając teorię w terminie późniejszym, czy też - polegając na intuicji jedynie...”. Dobrym przykładem jest tutaj znowu Kraków. Jak stwierdza Alina Kozarkiewicz, w ramach współpracy instytucji kultury i uczelni w Krakowie tworzone są inicjatywy badawcze dotyczące kultury (np. diagnozy), wspierane przez instytucje samorządowe (np. Małopolski Instytut Kultury). Istnieją również fundacje wspierające taką współpracę.

Krzysztof Stachowiak uważa, że być może nie należy jeszcze mówić o środowisku, ale o ośrodkach skupionych wokół konkretnych osób. Poza najważniejszym ośrodkiem krakowskim badacz wymienia takie uczelnie, jak: Uniwersytet Ekonomiczny w Krakowie, Szkoła Główna Handlowa w Warszawie, Uniwersytet Kardynała Stefana Wyszyńskiego w Warszawie, Uniwersytet Warszawski, a także Uniwersytet im. Adama Mickiewicza w Poznaniu, Uniwersytet Wrocławski, Uniwersytet Śląski i Uniwersytet Ekonomiczny w Katowicach. Wypowiedź Konrada Klejsy skłania, by dodać do tej listy jego rodzimy Uniwersytet Łódzki. Z kolei Joanna Śmietanka zwraca uwagę na znaczenia działalności Narodowego Centrum Kultury w Warszawie, w którym „zadaniem statutowym jest podejmowanie działań na rzecz rozwoju kultury w Polsce, między innymi poprzez edukację kulturalną oraz zwiększanie zainteresowania kulturą i sztuką, rozwój i profesjonalizację sektora kultury, promocję polskiego dziedzictwa narodowego oraz podtrzymywanie i upowszechnianie tradycji narodowej i państwowej”.

Urszula Grzelońska przy pracy nad książką Ekonomiczna strona kultury korzystała z lektury prac np. socjologa kultury prof. Mariana Golki oraz kulturoznawcy prof. Jacka Sójki (obaj z Uniwersytetu im. Adama Mickiewicza). Badaczka podkreśliła również dorobek prof. Doroty Ilczuk związanej z kulturoznawstwem na Uniwersytecie Humanistycznym SWPS. Z kolei Agata Siwiak zwróciła uwagę na dorobek zespołu kierowanego przez prof. Jerzego Hausnera w Katedrze Gospodarki i Administracji Publicznej na Uniwersytecie Ekonomicznym w Krakowie (to zresztą, obok ośrodka z Uniwersytetu Jagiellońskiego, jeden z pionierów polskiego zarządzania kulturą):

Ja sama staram się skupiać na tym, co robię na mojej uczelni - w Instytucie Teatru i Sztuki Mediów UAM - czyli też działam w pewnej izolacji. Na UAM prowadzę specjalizację dla kuratorów i producentów teatralnych, której finałem jest Festiwal Nowa Siła Kuratorska, w ramach którego studenci 
rokrocznie przygotowują autorskie projekty artystyczne. Programują je na poziomie artystycznym i produkują: zdobywają środki finansowe, pieniądze, sieciują instytucje kultury, pozyskują partnerów i mecenasów. [...] Zarządzanie kulturą jest dyscypliną, którą warto badać przez praktykę.

Łukasz Wróblewski wspomina o działalności Wyższej Szkoły Biznesu w Dąbrowie Górniczej (WSB): uczelnia ta jest organizatorem cyklicznej Międzynarodowej Konferencji Naukowej „Współczesne problemy zarządzania i marketingu w instytucjach kultury", prowadzi również regularne badania w sektorze kultury na pograniczu polsko-czeskim. Marzenna Wiśniewska dodaje do tej listy Instytut Kultury Współczesnej UŁ oraz Wydział Humanistyczny UMCS w Lublinie. Jej zdaniem trudno jest jednak mówić w Polsce o środowisku badaczy zarządzania kulturą, gdyż jest to dyscyplina stosunkowo młoda i mało skonsolidowana w ośrodkach badawczych:

Zarządzaniem kulturą zajmują się badacze różnych dyscyplin i dla wielu $\mathrm{z}$ nich nie jest to główny nurt badań, ale dziedzina towarzysząca - dzieje się tak zarówno wtedy, gdy podstawowym obszarem badacza są nauki spoleczne, jak i w przypadku nauk humanistycznych (np. kulturoznawstwa). Brakuje w Polsce konferencji, sesji, programów, projektów, które umożliwiłyby spotkania i wymianę myśli oraz doświadczeń badaczy podejmujących zagadnienia związane z zarządzaniem kulturą.

$\mathrm{Na}$ bardzo ciekawy, niejako psychologiczny aspekt współpracy między badaczami zwrócił uwagę Konrad Klejsa, który zauważył, że „środowiska "znawców kultury« oraz osób chcących uchodzić za "ekspertów od zarządzania« są rozłączne, zbyt rzadko się zazębiają, a gdy na siebie natrafią, niekiedy trudno im się porozumieć”. Badacz podaje też jednak przykład z własnego doświadczenia, który pokazuje, ile można „ugrać” na współdziałaniu w tej dziedzinie: „Całkiem niedawno moja koleżanka z łódzkiego Instytutu Kultury Współczesnej oraz jej kolega z Instytutu Ekonomii napisali wspólnie artykuł o crowdfundingu i został on opublikowany w »topowym« czasopiśmie międzynarodowym z ministerialnej listy A. I tego rodzaju inicjatywy - wspólne, kulturoznawców i ekonomistów lub prawników - mają według mnie przyszłość". 


\section{Z PUNKTU WIDZENIA PRAKTYKA}

Niezaprzeczalną wartością ankiety okazało się włączenie do rozmowy praktyków, którzy na co dzień, czasami intuicyjnie, starają się dostosować dostępne narzędzia i modele do codziennego zarządzania instytucją kultury, projektem, organizacją. Interesujące jest podejście do zarządzania przedstawione przez Iwonę Haberny, która twierdzi, że:

Chodzi o stworzenie warunków, w których kultura (twórcy i ich publiczność) może się najpełniej rozwijać. [...]. Potrzebna jest osobna refleksja teoretyczna, która pozwoli ustalić priorytety, kryteria i długofalowe cele. Natomiast wdrażanie tego wymaga otwarcia się na wiedzę już wypracowaną - zarządzanie, marketing, promocję. W tym wypadku nie widzę powodu, by wyważać otwarte drzwi i tworzyć nowe teorie na potrzeby kultury.

Ida Bocian (Teatr Gdynia Główna) zauważyła natomiast, że „metody działania (nawet zarządzania) należy dostosowywać na bieżąco do wyznaczonych celów, zespołu ludzkiego, z którym mam pracować, struktury, w którą wchodzę (jako pracownik i zarządzający), a w szczególności - potrzeb odbiorców naszych działań. To oczywiście wymaga od zarządzającego elastyczności, ale również zaryzykowania i pewnych założeń wstępnych, których skuteczność możemy w trakcie realizacji zadań sprawdzać”. Kamila Lewandowska $z$ kolei podkreśliła konieczność „dostosowania” klasycznych metod zarządzania do działalności kulturalnej:

Wiele prac poświęconych zarządzaniu lub marketingowi kultury opiera się na (zbyt) dosłownym zapożyczaniu rozwiązań z zarządzania biznesowego. Publikacje te są ciężko przyswajalne dla studentów i mało przydatne dla praktyków. Udane publikacje/szkolenia/zajęcia powinny raczej opierać się na pogłębionej analizie ciekawych przypadków (case studies), a w mniejszym stopniu na modelach, diagramach i definicjach w formie bullet points. Dobrych wzorców dostarczają kraje anglosaskie, gdzie nauczanie zarządzania opiera się na analizie przypadków.

Joanna Śmietanka puentuje: „Pamiętać należy przy tym, że zarządzanie kulturą nie tworzy kultury, ale ją umożliwia. Polega przede wszystkim na dostarczaniu dóbr kulturalnych poprzez umiejętne zarządzanie tworami kultury, ale też ośrodkami, w których one powstają". 


\section{ZAKOŃCZENIE}

Na koniec warto przywołać refleksję Urszuli Grzelońskiej, która zwróciła uwagę na ścisły związek między zarządzania kulturąa a życiem:

Najważniejszą sprawą zarządzania w kulturze w dzisiejszych czasach jest odpowiednie umotywowanie ludzi - odbiorców kultury, nie tylko aby chcieli korzystać z obecnych i dawniej wytworzonych dóbr kultury, ale też aby zechcieli płacić za wytworzenie i ochronę dziedzictwa kulturowego, i to płacić nie tylko za bilety wstępu do instytucji kulturalnych, ale aby poczuwali się do obowiązku filantropii na rzecz kultury. Uczenie zarządzania w kulturze to, moim zdaniem, uczenie ludzi, jak fachowo organizować sponsoring różnych działań kulturalnych wśród różnych grup społecznych i dochodowych, a nie tylko szukać sponsorów w grupie kilku banków i firm przetwarzających ropę naftową. Rozważenie różnych możliwych teoretycznie sposobów organizowania i finansowania działalności kulturalnej uczy, że polegając tylko na rynku i na państwie, w żadnym kraju nie osiągnie się satysfakcjonującej intensywności życia kulturalnego, spełniającego oczekiwania każdego odbiorcy.

Autorefleksyjną dyskusję na temat zarządzania w kulturze zamyka dłuższa wypowiedź prof. Emila Orzechowskiego, twórcy słynnego krakowskiego ośrodka i jednego z polskich pionierów zarządzania kulturą.

Emil Orzechowski (UJ)

\section{Zarządzanie kulturą a zarządzanie w kulturze}

Małe, niepozorne „a”, lecz wielką różnicę czyni. Tak mi się przynajmniej wydaje, choć refleksji na ten temat w polskiej literaturze nie znajduję. Moim zdaniem „zarządzanie kulturą” to sfera polityczna, „zarządzanie w kulturze” to pragmatyka sektora kultury. Jest to ważne, wręcz zasadnicze rozróżnienie kompetencji, a zatem i zakresów odpowiedzialności. Rzecz jasna, aby móc sensownie rozmawiać o tych kwestiach, należy najpierw uzgodnić zakres pojęcia zasadniczego - „kultura”. Do wyboru jest tu albo lapidarne, lecz wartościujące określenie Karola Wojtyły, zgodnie z którym „kulturą godzi nazywać się to wszystko, co przyczynia się pozytywnie do rozwoju człowieka"12, albo chłodna, technokratyczna, amerykańska definicja przyjęta

12 Konstytucja duszpasterska o Kościele w świecie współczesnym „Gaudium et spes”, [w:] Sobór Watykański II. Konstytucje, dekrety, deklaracje, Poznań 2002, nr 53. 
i popularyzowana u nas przez Piotra Sztompkę, która mówi, że kultura obejmuje „wszystko, co ludzie czynią, myślą i posiadają jako członkowie społeczności”'13 (kultura symboliczna, materialna, normatywna). Definicja ta pozwala na domniemanie, że cała ta sfera podlega wpływom politycznym, a jej możliwości określa to, co w teorii zarządzania Ricky W. Griffin nazywa otoczeniem ogólnym w wymiarze prawno-politycznym, socjokulturowym, międzynarodowym etc. ${ }^{14}$ Jej zastosowanie w kategoriach zarządzania w kulturze umożliwia ważne dopełnienie Antoniny Kłoskowskiej, która dostrzega „instytucjonalny układ kultury [...] w ramach określonych specjalnymi regułami formalnie zorganizowanych instytucji, na przykład szkół, kościołów, teatrów, filharmonii, domów kultury"15. Jednak i ona dodaje, że „ten układ podlega zwykle kontroli szerszych organizacji wchodzących w skład socjetarnej kultury, jest przedmiotem wpływów polityki kulturalnej lub pluralistycznych polityk kulturalnych"16. Z takiego ujęcia wynika, że między zarządzaniem kulturą (polityką kulturalną) a zarządzaniem w kulturze nie powinno być niejasności, a już szczególnie sprzeczności - to drugie powinno logicznie i harmonijnie wynikać z pierwszego. Czy tak jest u nas istotnie?

Nie jest, bo „państwo polskie mózgu jest pozbawione” (Jerzy Hausner ${ }^{17}$ ) i nie ma żadnej racjonalnie wypracowanej polityki kulturalnej. Prezes Polskiej Akademii Nauk, prof. Michał Kleiber, skomentował sytuację nie mniej drastycznie: „Polska jest rzadkim przykładem cywilizowanego kraju, w którym nie istnieje ośrodek studiów strategicznych [...]. Politycy nie są zainteresowani niezależnymi ekspertyzami, bo obawiają się, że mogą krępować swobodę ich działania"18.

Zasady polityki kulturalnej muszą być oparte na gruntownej znajomości faktów - faktów zinterpretowanych przez wnikliwych analityków, których opracowania zrecenzują wybitni eksperci, tak akademicy, jak i praktycy, a następnie zostaną one poddane publicznej dyskusji i uchwalone przez Sejm

13 P. Sztompka, Socjologia: analiza społeczeństwa, Kraków 2002, s. 233.

14 R.W. Griffin, Podstawy zarządzania organizacjami, tłum. M. Rusiński, Warszawa 2004, s. 77.

15 A. Kłoskowska, Społeczne ramy kultury. Monografia socjologiczna, Warszawa 1972, s. 41.

${ }^{16}$ Ibidem.

17 Cyt. za: E. Bendyk, Gdzie Tusk ma mózg?, „Polityka”, www.polityka.pl/ tygodnikpolityka/kraj/1536403,1,gdzie-jest-mozg-polskiego-panstwa.read [dostęp: 8.11.17].

18 Ibidem. 
czy przyjęte przez Rząd. Aby dokument taki mógł powstać, potrzebne jest prowadzenie systematycznych badań. Jak je zorganizować? - podpowiedzi udziela Mark J. Schuster w książce Informacja w polityce kulturalnej, będącej przeglądem chyba wszystkich istotnych światowych wzorców. Jakie będą tego konsekwencje? - niesłychanie ważne, gdyż polityka kulturalna to, moim zdaniem, nic innego jak odpowiednik misji w procesach zarządzania. A wiadomo, że od misji wszystko się zaczyna. Misja wskazuje wartości, krąg odbiorców, sposoby działania. Misja integruje, wskazuje na wyjątkowe walory oferty. Państwa, w których takie studia były i są prowadzone, dopracowały się precyzyjnych nazw resortów, w jakich mieści się kultura, i, co ciekawe, chyba nigdzie nie występuje ona bez partnera, którym może być sport, turystyka, często edukacja, a nawet i rynek pracy (sic!). W Polsce nazwa ministerstwa ulega zmianie, kiedy tak sobie wymyśli dany minister lub - co gorsze - jego partia. Co jednak znaczy obecny „partner” kultury „dziedzictwo narodowe” - dalibóg, nie wiem. Nie sądzę też, by twórca tego dopełnienia, Kazimierz Michał Ujazdowski, miał na uwadze te wartości (i metody ich implementacji), jakim hołduje dziś minister Piotr Gliński. Ale skoro wiemy, że „dziedzictwo narodowe” oznaczać może bardzo różne wartości, przyzwoitość nakazuje, aby je dookreślić. M.J. Schuster pisze wprost: „Jest, czy też i nie, politycznie poprawne używanie słów »polityka kulturalna« w uładzonym towarzystwie, każde społeczeństwo ma jakąś i powinno to być oczywistością, że mamy możność oceniać, jak ona funkcjonuje”, i niejako ostrzega: „Polityka może być wyłożona klarownie [explicit], i w takim przypadku może być wyczytana w istniejących dokumentach, albo też może być ukryta [implicit], a wówczas można o niej wnioskować na podstawie oświadczeń i działań” ${ }^{\prime 19}$. Zapewne wielka musiała być frustracja i konfuzja znakomitego skądinąd dziennikarza „Polityki”, który napisał kilkanaście lat temu: „na rynku, gdzie znalazła się w ostatniej dekadzie także kultura, nikt nie pyta przecież o idee”, i jeszcze, co gorsza, dodał: „Rząd obiecuje, że zadba o pieniądze, ale przecież na tym - na szczęście - kończy się dzisiaj polityka kulturalna państwa”" ${ }^{20}$. Co więcej, w tym samym numerze „Polityki” jego nie mniej znakomity kolega w artykule pod wymownym tytułem Nie porzucaj mnie rozpaczliwie błagał o regulacje, które spowodują, że „bogaci

19 M.J. Schuster, Informacja w polityce kulturalnej. Infrastruktura informacyjna i badawcza, tłum. M. Król, Kraków 2007, s. X.

20 Z. Pietrasik, Rząd założy kabarety, „Polityka”, https://archiwum.polityka. $\mathrm{pl} / \mathrm{art} / \mathrm{rzad}-\mathrm{zalozy}-\mathrm{kabaret}, 373328 . \mathrm{html}$, [dostęp: 15.11.17]. 
i twórczy znów padną sobie w ramiona”21. Jak to możliwe przy braku polityki kulturalnej - doprawdy, nie wiadomo... Amerykanie, którzy też nie mają polityki kulturalnej wyrażonej explicite, de facto realizują ją bez deklaracji i na swój pragmatyczny sposób: poprzez regulacje podatkowe, sprzyjanie fundacjom i wszelkim inicjatywom obywatelskim.

$\mathrm{Z}$ tego, co napisałem, wynika jeden wniosek: polityka kulturalna jest zarządzaniem kulturą, i z niej dopiero wyprowadzone mogą być sposoby zarządzania w kulturze. Jasno pisze o tym Schuster: „Dopiero wówczas, gdy zasady polityki kulturalnej są określone, potrzeba planowania staje się oczywista. Plany obejmują strategię, zestaw działań, które pozwolą nam na przejście z miejsca, w którym jesteśmy, na miejsce, w którym chcielibyśmy być. Plan opiera się na możliwie najlepszym rozpoznaniu tego, jaki rodzaj działań jest najlepszy dla osiągnięcia zakładanych celów przy najsprawniejszym wykorzystaniu dostępnych zasobów"22.

Zarządzanie, rzecz jasna, miało i ma na celu realizację misji w sposób „sprawny i skuteczny” (R.W. Griffin) ${ }^{23}$. Mimo że - podobnie jak kultura obecne było od zawsze, zaczęło być traktowane serio dopiero wówczas, gdy i maszyna, i wykorzystanie jej możliwości stały się - z punktu widzenia rentowności - ważniejsze od człowieka. Kwestia, jak sprawić, by człowiek nadążał za maszyną, była główną troską klasyków zarządzania. W ten sposób zarządzanie trafiło w zazdrosne ręce wąsko patrzących ekonomistów, zysk li tylko materialny mających na uwadze. Trzeba było wielu lat, by nieco inne spojrzenie zostało potraktowane serio. To nowe spojrzenie to myśli Petera Druckera, który w roku 1969 napisał: „Zarządzanie będzie musiało być traktowane jako "nauka ścisła» $\mathrm{i}$ »humanistyka« [science and humanity]", i objaśniał to w ten sposób: „Zarządzanie jest również kulturą i systemem wartości i przekonań. Jest też środkiem, za pomocą którego dane społeczeństwo uruchamia swoje własne wartości i przekonania. Zarządzanie może być uznawane za pomost między cywilizacją [...] i kulturą, która wyraża rozmaite tradycje, wartości, wierzenia i dziedzictwo. Zarządzanie musi stać się instrumentem, za pomocą którego różnorodność kulturowa będzie służyć wspólnym celom ludzkości”. Badacz konkludował, że „jeśli zarządzanie nie zdoła uruchomić specyficznego dziedzictwa kultury danego kraju i narodu,

${ }^{21}$ P. Sarzyński, Nie porzucaj mnie, „Polityka”, https://archiwum.polityka.pl/ art/nie-porzucaj-mnie,375622.html [dostęp: 8.11.17].

22 M.J. Schuster, op. cit., s. X.

${ }^{23}$ R.W. Griffin, op. cit., s. 6. 
nie zaistnieje rozwój społeczny i ekonomiczny"24. Trzeba było wielu lat, by Lawrence E. Harrison i Samuel Huntington wydali zbiorową pracę pod tytułem Kultura ma znaczenie ze znaczącym podtytułem: Jak wartości wpływaja na rozwój społeczeństw ${ }^{25}$.

W Polsce myślom takim przebić się nie było - a i nadal nie jest - łatwo, mimo oryginalnego wkładu do nauki światowej takich myślicieli, jak Florian Znaniecki czy Tadeusz Kotarbiński. Historia pierwszego w Polsce kierunku studiów z zakresu zarządzania kulturą dostarcza tu aż nadto wiele wymownych przekładów. Początkowo był to kierunek Zarządzanie i marketing, skąd został „przegoniony” decyzją Polskiej Komisji Akredytacyjnej, złożonej z samych ekonomistów. Potem był kierunek Sprawy publiczne - zgodnie z sugestią autorytetów z zakresu administracji. Hubert Izdebski i Michał Kulesza pisali: „wymogi ekonomiki, techniki i zarządzania nie są w stanie całkowicie wyeliminować ani odrębności narodowych, wynikających z tradycji historycznych, ani też faktu, że zarządzanie publiczne uwikłane jest zawsze w materie władzy publicznej, a »interes publiczny« nie zawsze daje się pogodzić z ogólnymi kryteriami efektywnościowymi”"26. Zarządzanie kulturą nie mieściło się jednak i w tym obszarze, bo kultura spełnia się we wszystkich sektorach, także prywatnym (rynek książki, dzieł sztuki). Potem było kulturoznawstwo, „śmietnik” o elitarnych ambicjach - dość powiedzieć, że na samym Uniwersytecie Jagiellońskim jest około trzydziestu kulturoznawstw, a próby ich sensownego zreformowania w kierunku scalenia są skazane na porażkę. Na zarządzanie kulturą/w kulturze nie było tam, zdaniem kulturoznawczych autorytetów, miejsca. A szkoda, bo wszystkimi procesami, jakimi zajmuje się kulturoznawstwo, także się zarządza, a im sprawniej i skuteczniej, tym lepsze są efekty. Ostatecznie - od czasu reformy kształtowania programów studiów - kierunek ten ma nazwę Zarządzanie kulturą i mediami, która definiuje pole akademickich zainteresowań tej nowej dyscypliny naukowej.

Oczywistością jest, że nie ma nauki bez metodologii. Tu tropy wskazywali nam ci, którzy byli pionierami na tym polu. Nieprzypadkowo pierwszym przetłumaczonym na polski i przez nas wydanym podręcznikiem

${ }^{24}$ P.F. Drucker, Management's New Role, „Harvard Business Revue” 1969, November-December, s. 49-54.

${ }^{25}$ L. Harrison, S. Huntington, Kultura ma znaczenie. Jak wartości wptywaja na rozwój społeczeństw, tłum. S. Dymczyk, Poznań 2003.

${ }^{26} \mathrm{H}$. Izdebski, M. Kulesza, Administracja publiczna. Zagadnienia ogólne, Warszawa 2004, s. 298. 
była książka Giepa Hagoorta Przedsiębiorczość w kulturze ${ }^{27}$, potem prace Petera Bendixena ${ }^{28}$, Marka J. Schustera i in. Wielki materiał do przemyślenia przyniosły wykłady ambasadorów na temat polityki kulturalnej ich kraju. Owocem poszukiwań i testowania metodologii były kolejne prace doktorskie, habilitacyjne czy tak zwane profesorskie, najczęściej wydawane we własnej serii „Biblioteka Zarządzania w Kulturze”. Jej funkcję spełniają dziś wydawnictwa między innymi Narodowego Instytutu Kultury, dysponującego środkami nieporównanie większymi niźli uniwersytet. Co jest przy tym ważne, może i najważniejsze, to fakt, że w owe metodologiczne poszukiwania włączyło się już wielu ekonomistów. Nowe impulsy dały prace Doroty Ilczuk $^{29}$, Łukasza Sułkowskiego ${ }^{30}$ i wielu innych, natomiast ostatnio wiele w tej materii uczyniła Monika Kostera, publikując między innymi Manifest humanistyczny o zrównoważone zarządzanie, w którym dobitnie zaznaczyła: „Nadszedł dla nas, zwykłych ludzi, czas, żeby odzyskać zarządzanie”, co $\mathrm{w}$ tym przypadku wskazuje na proces prowadzony $\mathrm{z}$ myślą o poszukiwaniu zarządzania humanistycznego i zarządzania w humanistyce ${ }^{31}$.

Nie ma nauki bez prowadzenia badań i upowszechniania ich wyników. Powołaliśmy zatem na UJ dwa czasopisma naukowe: „Zarządzanie w Kulturze” oraz międzynarodowe „Culture Management”, a także serię wydawniczą „Biblioteka Zarządzania w Kulturze”, w której wyszło wiele prac tłumaczonych i sporo oryginalnych, pionierskich w Polsce. Było to wszystko możliwe wyłącznie dzięki pełnej zaufania dla inicjatorów zarządzania w naukach humanistycznych decyzji Centralnej Komisji ds. Stopni i Tytułów Naukowych uznającej prawo Wydziału Zarządzania i Komunikacji Społecznej UJ do nadawania stopni i tytułów w zakresie nauki humanistyczne, dyscyplina: zarządzanie.

Wydaje się, że na poziomie najogólniejszym kwestie sporne wokół ulokowania zarządzania kulturą/w kulturze w sieci akademickich dziedzin załatwia, a tym samym i wszystkie spory likwiduje, ujęcie św. Tomasza z Akwinu, przypomniane przez Jana Pawła II na spotkaniu z rektorami

${ }^{27}$ G. Hagoort, Przedsiębiorczość w kulturze. Wprowadzenie do zagadnień zarządzania w kulturze, tłum. B. Bezemer-Szefke, E. Orzechowski, Kraków 1996. ${ }_{28}$ P. Bendixen, Wprowadzenie do ekonomiki kultury i sztuki, tłum. K.D. Kopeć, Kraków 2001.

29 D. Ilczuk, op. cit.

30 Ł. Sułkowski, Kulturowa zmienność organizacji, Warszawa 2002.

${ }_{31}$ M. Kostera, Manifest humanistyczny o zrównoważone zarządzanie, [w:] Zarządzanie. Kultura - media - dziedzictwo, Kraków 2013, s. 14. 
polskich uniwersytetów: „Genus humanum arte et ratione vivit: arte et ratione”32. Zamiast alternatywy mamy tu spójnik „i” - to wielka różnica. Jan Paweł II objaśniał to w sposób następujący: „A więc nauka, człowiek żyje nauką! Nauką, czyli poszukiwaniem prawdy o samym sobie i świecie otaczającym, wreszcie o Bogu. Człowiek jest nie tylko twórcą kultury, ale żyje kulturą i żyje poprzez swoją kulturę. To samo należy powiedzieć o narodzie. Także naród żyje kulturą i żyje poprzez swoją kulturę. Ona jest fundamentem jego duchowej suwerenności”. Oddając te kwestie pod rozwagę i opiekę uczonych, ostrzegał: „Sytuacja demokracji i wolności wymaga od środowisk akademickich wiele inicjatywy, wiele przedsiębiorczości, rzec można, i poczucia odpowiedzialności. Wymaga także czujności, ażeby wolności, z takim trudem i za taką cenę odzyskanej, nie tracić pod wpływem rozmaitych presji czy manipulacji, od których nie są wolne również współczesne demokracje”. Nazwał je po imieniu: „Obecnie pojawiają się nowe trudności i nowe zagrożenia. Jednym $\mathrm{z}$ nich w systemie liberalnej demokracji i wolnego rynku jest postawa skrajnego utylitaryzmu. Szerzy się bowiem sposób myślenia, który kryterium korzyści ekonomiczne uważa za normę najważniejszą i aplikuje ją do wszystkich dziedzin życia - także do sfery kultury i nauki”33.

Warto zauważyć, że R. Griffin, autor jednego z najbardziej popularnych akademickich podręczników na temat zarządzania - Podstawy zarządzania organizacjami - uważał podobnie, skoro we wstępie do swego dzieła stwierdził, że największymi menedżerami tego świata są: papież (gdy pisał te słowa, był nim Jan Paweł II) oraz prezydent Stanów Zjednoczonych ${ }^{34}$. Podobne uprawnienia, w stosownej skali, przypisywał dyrektorowi muzeum sztuki, prezesowi piłkarskiego klubu etc. To, że zajął się potem zarządzaniem zorientowanym na zysk ekonomiczny, nie zmieniło jego zasadniczego przekonania, że ogólne reguły zarządzania dotyczą instytucji i organizacji wszelkiego rodzaju. Jedyne, co je różni, to misja i zawarte w niej wartości, a także fakt, że dla różnego kręgu organizacji najważniejsze będą różne rodzaje zasobów; w sferze kultury nie są to zasoby materialne, lecz ludzie.

W latach ostatnich pojawiły się też i inne zagrożenia, których nawet święty nie był w stanie przewidzieć. W ich kontekście menedżer kultury

32 Wystąpienie ojca świętego Jana Pawła II podczas spotkania z rektorami polskich uniwersytetów, które odbyło się 4 stycznia 1996 roku w Watykanie. https:/w2.vatican.va/content/john-paul-ii/pl/speeches/1996/january/documents/ hf_jp-ii_spe_19960104_rettori-polonia.pdf [dostęp: 8.11.2017].

33 Ibidem.

34 R.W. Griffin, op. cit, s. 7. 
musi pamiętać o słowach Władysława Stróżewskiego, który definiuje dwa pojęcia kluczowe, niesłychanie dziś ważne przy budowaniu misji (polityki kulturalnej): „etyka obywatelska” $\mathrm{i}$ „etyka obywatela”35. Pierwsza z nich jest „etyką powinności, etyką obowiązku” ${ }^{6}$ i „dotyczy wszystkich obywateli, przede wszystkich jednak tych, którzy pretendują do podjęcia władzy"37. Z kolei „etyka obywatela to etyka odpowiedzialności”38. Stróżewski dodaje: „Punktem odniesienia etyki obywatelskiej jest państwo i jego prawa. Punktem odniesienia etyki obywatela jest ojczyzna"39, i wzmacnia to stwierdzenie cytatem z Cypriana Kamila Norwida: „Ojczyzna to wielki zbiorowy obowiązek". Ironią losu jest to, że pochodzi on z tekstu Memoriał o młodej emigracji.

W „Polityce” Jan Hartman pisze: „Każdy patrzy wszak tylko, gdzie by tu wyjechać albo załapać się na stypendium lub grant" ${ }^{\text {"40 }}$, a Włodzimierz Borodziej dodaje: „W Polsce nie idea europejska ma poparcie większości, lecz europejskie subwencje [...]. A gdy subwencje się skończą, to niech się rozleci. Usunięcie europejskich flag przez Beatę Szydło było wyraźnym sygnałem. Europa to subwencje i jak najmniej zobowiązań. W najlepszym razie strefa wolnego handlu"41. A więc jednak święty przewidział - przed tym właśnie nas ostrzegał.

\section{Bibliografia}

Peter Bendixen, Wprowadzenie do ekonomiki kultury i sztuki, tłum. K.D. Kopeć, Wydawnictwo UJ, Kraków 2001.

Rudolf Bing, 5000 wieczorów w operze, tłum. W. Kalinowski, PIW, Warszawa 1982. Szymon Cyfert, Wojciech Dyduch, Dominika Latusek-Jurczak, Jerzy Niemczyk, Agnieszka Sopińska, Subdyscypliny w naukach o zarządzaniu - logika

35 W. Stróżewski, O wielkości. Szkice z filozofii człowieka, Kraków 2002, s. 228.

36 Ibidem.

37 Ibidem.

38 Ibidem, s. 232.

39 Ibidem, s. 236.

40 J. Hartman, Inteligencja 2.0, „Polityka” 2016, nr 3049, s. 95.

41 A. Krzemiński, Pawie narodów, [Rozmowa z prof. W. Borodziejem], „Polityka”, https://archiwum.polityka.pl/art/pawie-narodow,449841.html [dostęp: 12.11.17]. 
wyodrębniania, identyfikacja modelu koncepcyjnego oraz zawartość tematyczna, „Organizacja i Kierowanie” 2014, nr 1(161), s. 37-48.

Peter F. Drucker, Management's New Role, „Harvard Business Revue” 1969, November-December, s. 49-54.

RickyW. Griffin, Podstawy zarządzania organizacjami, tłum. M. Rusiński, Wydawnictwo Naukowe PWN, Warszawa 2004.

Urszula Grzelońska, Ekonomiczna strona kultury, Wydawnictwo Key Text, Warszawa 2016;

Giep Hagoort, Przedsiębiorczość w kulturze. Wprowadzenie do zagadnień zarzadzania w kulturze, tłum. B. Bezemer-Szefke, E. Orzechowski, Wydawnictwo UJ, Kraków 1996.

Lawrence E. Harrison, Samuel P. Huntington Kultura ma znaczenie. Jak wartości wpływaja na rozwój społeczeństw, tłum. S. Dymczyk, Zysk i S-ka, Poznań 2003.

Dorota Ilczuk, Ekonomika kultury, Wydawnictwo Naukowe PWN, Warszawa 2012. Hubert Izdebski, Michał Kulesza, Administracja publiczna. Zagadnienia ogólne, „Liber”, Warszawa 2004.

Rafał Kasprzak, Przemysty kreatywne w Polsce: uwarunkowania i perspektywy, Kamon Consulting, Warszawa 2013.

Antonina Kłoskowska, Społeczne ramy kultury. Monografia socjologiczna, PWN, Warszawa 1972

Konstytucja duszpasterska o Kościele w świecie wspótczesnym „Gaudium et spes”, [w:] Sobór Watykański II. Konstytucje, dekrety, deklaracje, Pallotinum, Poznań 2002, nr 53

Monika Kostera, Manifest humanistyczny o zrównoważone zarządzanie, [w:] Zarządzanie. Kultura - media - dziedzictwo, Attyka, Kraków 2013, s. 9-14.

Gregory Ferrell Lowe, Introduction: What's So Special About Media Management, [w:] Managing Media Firms and Industries. What's So Special About Media Management, red. G.F. Lowe, Ch. Brown, Springer, New York - Dordrecht London 2016, s. 3-4.

Mark Davidson J. Schuster, Informacja w polityce kulturalnej. Infrastruktura informacyjna i badawcza, tłum. M. Król, Wydawnictwo UJ, Kraków 2007.

Krzysztof Stachowiak, Problemy metodologiczne badania sektora kreatywnego, „Rozwój Regionalny i Polityka Regionalna” 2015, nr 30, s. 14-16.

Władysław Stróżewski, O wielkości. Szkice z filozofii człowieka, Znak, Kraków 2002. 
Łukasz Sułkowski, Kulturowa zmienność organizacji, Polskie Wydawnictwo Ekonomiczne, Warszawa 2002.

Piotr Sztompka, Socjologia: analiza społeczeństwa, Znak, Kraków 2002.

David Throsby, Ekonomia i kultura, tłum. O. Siara, Narodowe Centrum Kultury, Warszawa 2010.

Ruth Towse, Ekonomia kultury. Kompendium, tłum. Ł. Skrok, H. Dębowski, K.L. Pogorzelski, Narodowe Centrum Kultury, Warszawa 2011.

\section{Around Cultural Management. The Outcome of the Research Survey}

In the spring of 2017 we conducted a survey among researchers in the broadly understood creative sectors, and among managers, often combining experience in this field with academic practice. We asked, among other things, about the cultural management, the specificity of this research area, and the most important environments dealing with this subject. Twenty people responded to our request. The results of this - in fact, self-reflective - research is presented below. Subjective attitude of the respondents to the problems, diversity of positions, and in many points also their convergence form the foundation on which to build research exploration in this area and find, still numerous, white spots.

Keywords: cultural management, culture studies, economy of the culture, interdisciplinary approach, creative industries 